\title{
Mikrostruktura połączeń różnorodnych stali 17-4PH ze stopami niklu
}

\section{Microstructure of disimilar joints of $17-4 \mathrm{PH}$ steel and nickel alloys}

\section{Streszczenie}

Łączenie materiałów róźnorodnych ma duże znaczenie w przemyśle lotniczym i nuklearnym. Wykonano połączenia różnorodne Inconel 625 - stal 17-4PH, Inconel 750 - stal 17-4PH metodą spawania plazmowego. Przeprowadzono badania mikrostruktury spoin za pomocą mikroskopu świetlnego i skaningowego, wykonano pomiary twardości w spoinie, strefie wpływu ciepła i materiale rodzimym. Badania wykazały, że metoda spawania plazmowego przy zastosowaniu odpowiednich parametrów spawania może być także stosowana przy otrzymywaniu połączeń różnorodnych stali $17-4 \mathrm{PH}$ ze stopami niklu.

\section{Wstęp}

Wraz z rozwojem wielu gałęzi przemysłu wzrasta zapotrzebowanie na materiały metaliczne o szczegól-

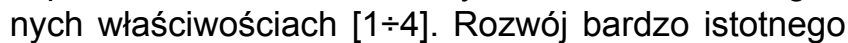
w naszych czasach przemysłu energetycznego pociąga za sobą nie tylko konieczność coraz częstszego stosowania materiałów odpornych na działanie różnych środowisk korozyjnych, ale także łączenia ich ze sobą. Materiały te często muszą zachowywać swoje właściwości również podczas eksploatacji w wysokiej temperaturze. Zarówno stopy niklu, takie jak Inconel 625 czy Inconel 750, jak i stal 17-4PH spełniają te wymagania. Ze względu na różne wymagania stawiane częściom elementów konstrukcyjnych, może okazać się konieczne wykonywanie połączeń różnorodnych $z$ udziałem tych metali. Połączenia różnorodne omawianych materiałów mogą znaleźć

Dr inż. Aneta Ziewiec, dr inż. Janusz Stępiński, prof. dr hab. inż. Edmund Tasak - AGH Akademia Górniczo-Hutnicza, Kraków. zastosowania w rafineriach, wymiennikach ciepła, energetyce, przemyśle chemicznym, nuklearnym, spożywczym, czy też przy budowie silników odrzutowych i rakietowych. Łączenie różnych metali ma szczególne znaczenie $w$ lotnictwie i energetyce [5]. Połączenia różnorodne prawie zawsze powodują zmiany w mikrostrukturze, co może wpływać na pogorszenie właściwości mechanicznych materiałów. Chociaż zarówno stop Inconel 625, Inconel 750, jak i stal $17-4 \mathrm{PH}$ są często stosowane i spawane pojedynczo [6], to jednak niewiele jest dostępnych informacji o połączeniach różnorodnych Inconelu 625, czy też 750 , ze stalą nierdzewną 17-4PH [5]. Dlatego też w niniejszej pracy skupiono się na badaniu mikrostruktury takich połączeń.

\section{Materiał i procedura badań}

W badaniach wykorzystano ze stali $17-4 \mathrm{PH}$ i stopów Inconel 625 oraz Inconel 750 o wymiarach $65 \times 25 \times 1 \mathrm{~mm}$. Skład chemiczny materiałów podstawo-

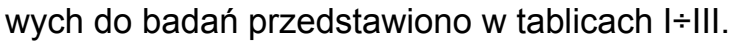


W blaszkach ze stali 17-4PH wycięto szczelinę szerokości ok. $1 \mathrm{~mm}$, w którą wsunięto blaszki ze stopów Inconel i następnie pospawano je metodą plazmową bez materiału dodatkowego. Parametry procesu przedstawiono w tablicy IV, a widok próbek po spawaniu na rysunku 1.

Tablica I. Skład chemiczny stali 17-4PH

Table I. Chemical composition of the 17-4PH steel

\begin{tabular}{|c|c|c|c|c|c|c|c|c|}
\hline Pierwiastek & $\mathrm{C}$ & $\mathrm{Cr}$ & $\mathrm{Ni}$ & $\mathrm{Cu}$ & $\mathrm{Si}$ & $\mathrm{Mn}$ & $\mathrm{Nb}$ & $\mathrm{Fe}$ \\
\hline$\%$ wag. & 0,06 & 16,5 & 4 & 3,4 & 0,6 & 0,6 & 0,3 & reszta \\
\hline
\end{tabular}

Tablica II. Skład chemiczny Inconelu 625

Table II. Chemical composition of the Inconel 625

\begin{tabular}{|c|c|c|c|c|c|c|c|c|c|c|c|}
\hline Pierwiastek & $\mathrm{Ni}$ & $\mathrm{Cr}$ & $\mathrm{Fe}$ & $\mathrm{Mo}$ & $\mathrm{Nb}$ & $\mathrm{C}$ & $\mathrm{Mn}$ & $\mathrm{Si}$ & $\mathrm{Al}$ & $\mathrm{Ti}$ & $\mathrm{Co}$ \\
\hline \% wag. & 58 & 22 & 5 & 9 & 3,4 & 0,1 & 0,4 & 0,4 & 0,3 & 0,4 & 1 \\
\hline
\end{tabular}

Tablica III. Skład chemiczny Inconelu 750

Table III. Chemical composition of the Inconel 750

\begin{tabular}{|c|c|c|c|c|c|c|c|c|c|c|c|}
\hline Pierwiastek & $\mathrm{Ni}$ & $\mathrm{Cr}$ & $\mathrm{Fe}$ & $\mathrm{Nb}$ & $\mathrm{C}$ & $\mathrm{Mn}$ & $\mathrm{Si}$ & $\mathrm{Cu}$ & $\mathrm{Al}$ & $\mathrm{Ti}$ & $\mathrm{Co}$ \\
\hline \% wag. & 70 & 15 & 7,9 & 1 & 0,08 & 1 & 0,5 & 0,5 & 0,7 & 2,25 & 1 \\
\hline
\end{tabular}

Tablica IV. Parametry procesu spawania

Table IV. Welding process parameters

\begin{tabular}{|c|c|}
\hline Gaz plazmowy & Ar, przepływ 0,3 I/min \\
\hline Gaz osłonowy & $\mathrm{Ar}+\mathrm{He}$, przepływ $9 \mathrm{I} / \mathrm{min}$ \\
\hline Natężenie prądu & $6 \div 11 \mathrm{~A}$ \\
\hline
\end{tabular}
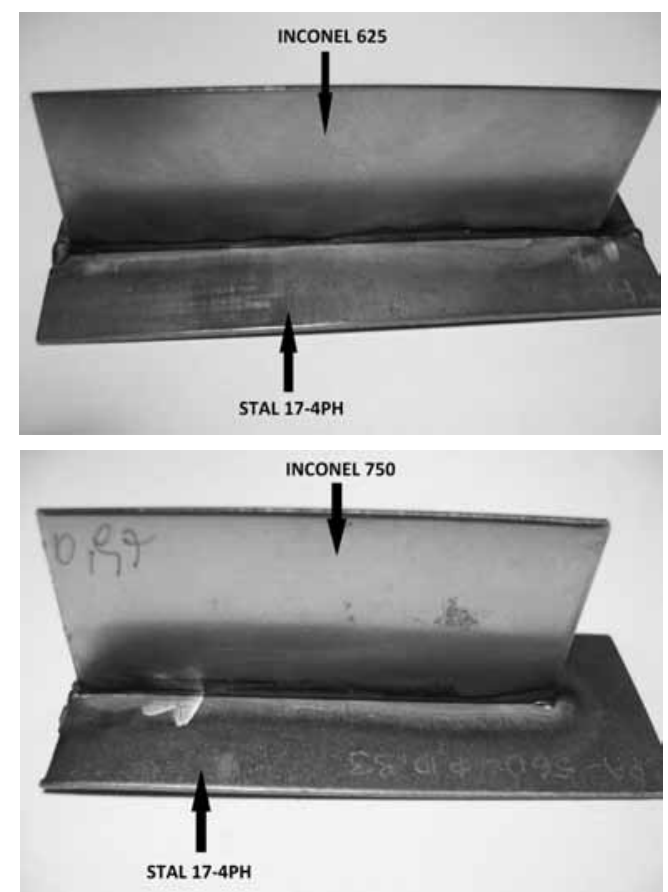

Rys. 1. Próbki po spawaniu: a) połączenie różnorodne stali 17-4PH ze stopem Inconel 625 , b) połączenie różnorodne stali $17-4 \mathrm{PH}$ ze stopem Inconel 750

Fig. 1. The appearance of the samples after welding: a) dissimilar joint of the 17-4PH steel and Inconel 625 , b) dissimilar joint of the 17-4PH steel and Inconel 750
Po spawaniu próbki zostały pocięte na cztery części i poddane badaniom przy użyciu mikroskopu świetlnego, SEM, badaniom rentgenowskim oraz wykonano pomiary twardości. Do badań mikrostruktury próbki zostały wyszlifowane ręcznie oraz wypolerowane mechanicznie z użyciem diamentowej pasty ściernej. Tak przygotowane próbki poddano trawieniu elektrolitycznemu w $10 \%$ wodnym roztworze $\mathrm{CrO}_{3}$. Pozwoliło to ujawnić mikrostrukturę stopów Inconel. W celu ujawnienia mikrostruktury stali $17-4 \mathrm{PH}$ wykonano dodatkowe trawienie w odczynniku Vilella. Analiza optyczna została przeprowadzona na mikroskopie świetlnym Leica, a obraz zarejestrowano sprzężoną z mikroskopem kamerą cyfrową.

Próbki do badań na skaningowym mikroskopie elektronowym (SEM) zostały dodatkowo mocniej wytrawione elektrolitycznie w $10 \%$ wodnym roztworze $\mathrm{CrO}_{3}$. Badania przeprowadzono na mikroskopie skaningowym Stereoscan 120.

Pomiary twardości próbek wykonano twardościomierzem Vickersa. Pomiary przeprowadzono w poprzek spoiny, SWC i materiału rodzimego, stosując obciążenie 49 N. Odległość między pomiarami wyniosła ok. 0,5 mm.

\section{Wyniki badań}

Mikrofotografie omawianych próbek ukazały mikrostrukturę różnych obszarów wykonanych połączeń spawanych. Na rysunku 2 przedstawiono materiały rodzime stopów Inconel 625 i Inconel 750 oraz stali 17-4PH. Badany stop Inconel 625 charakteryzuje się mikrostrukturą austenityczną z charakterystycznymi granicami bliźniaczymi (rys. 2a). Inconel 750 ma również strukturę austenityczną. Na mikrofotografii widoczne są wtrącenia niemetaliczne usytuowane wzdłuż kierunku walcowania (rys. 2b). Stal 17-4PH ma mikrostrukturę martenzytyczną (rys. 2c).

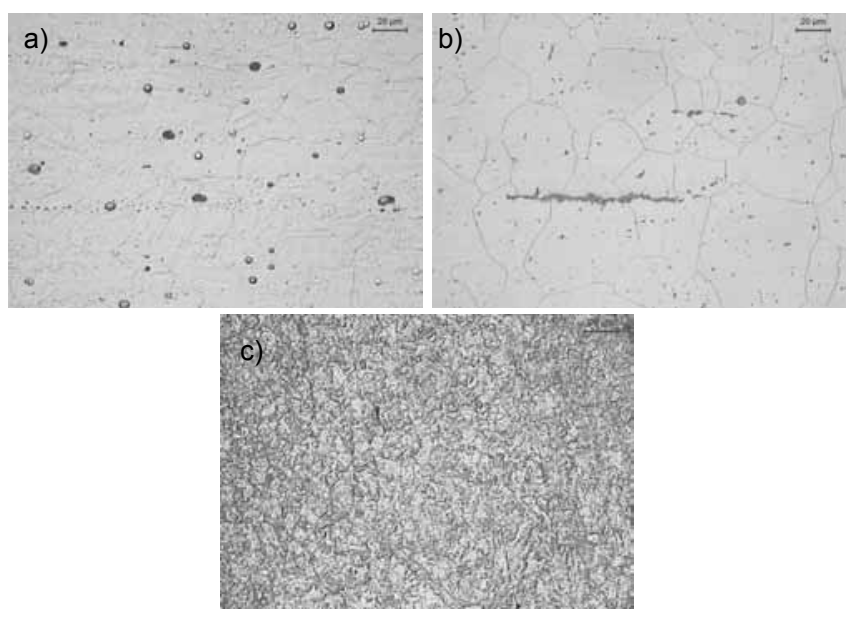

Rys. 2. Mikrostruktura materiału rodzimego: a) Inconel 625, b) Inconel 750, c) stal 17-4PH

Fig. 2. Microstructure of the base metal: a) Inconel 625, b) Inconel 750, c) $17-4 \mathrm{PH}$ steel 


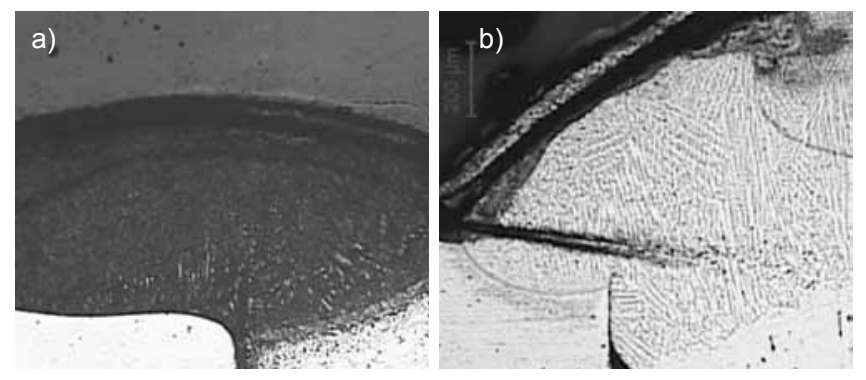

Rys. 3. Połączenia spawane plazmowo: a) między Inconelem 625 a stalą $17-4 \mathrm{PH}$, b) między Inconelem 750 a stalą $17-4 \mathrm{PH}$

Fig. 3. The appearance of the samples after plasma welding: a) dissimilar joint of the 17-4PH steel and Inconel 625, b) dissimilar joint of the $17-4 \mathrm{PH}$ steel and Inconel 750

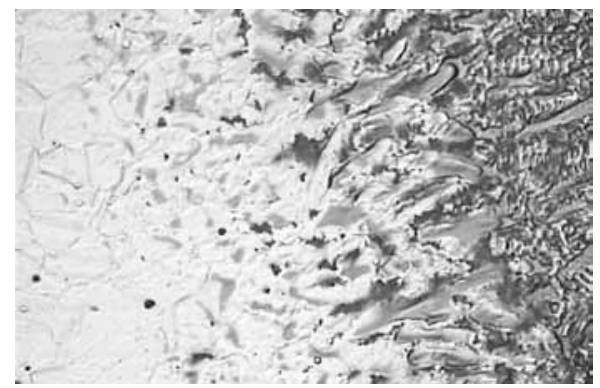

Rys. 4. Połączenie Inconel 625 - stal 17-4PH. Linia wtopienia pomiędzy Inconelem 625 i spoiną. Widoczna struktura komórkowo-dendrytyczna w spoinie

Fig. 4. Welded joint between Inconel 625 and 17-4PH steel; the fusion line between Inconel 625 and the weld; cellular-dendritic microstructure of the weld

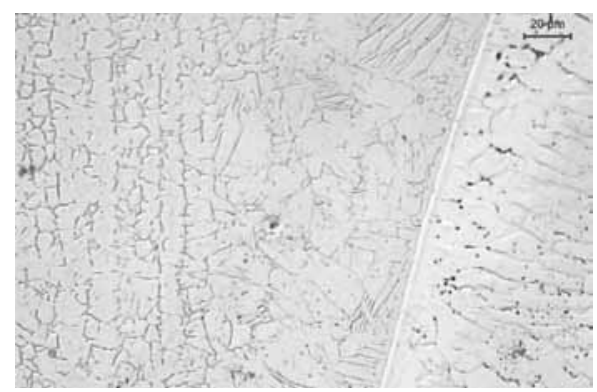

Rys. 5. Połączenie Inconel 750 - stal $17-4 \mathrm{PH}$. Linia wtopienia między stalą $17-4 \mathrm{PH}$ a spoiną, widoczny płaski front krystalizacji oraz struktura komórkowo-dendrytyczna w spoinie

Fig. 5. Inconel $750-17-4 \mathrm{PH}$ welded joint; the fusion line between $17-4 \mathrm{PH}$ steel and the weld, planar crystallization front and cellular-dendritic microstructure of the weld

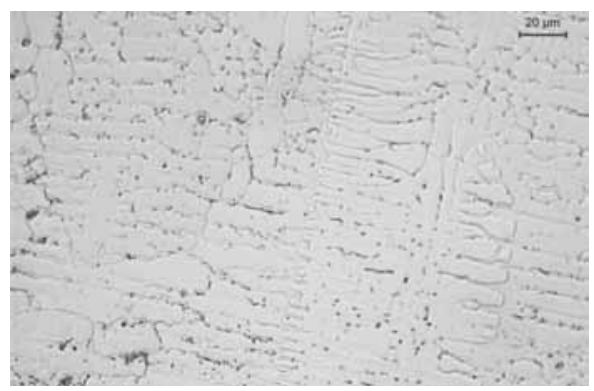

Rys. 6. Połączenie Inconel 750 - stal $17-4 \mathrm{PH}$. Spoina, widoczny front komórkowo-dendrytyczny Fig. 6. Welded joint between Inconel 750 and $17-4 \mathrm{PH}$ steel. The weld - appearance of the cellular-dendritic crystallization front
Na rysunku 3 przedstawiono strukturę połączeń między Inconelem 625 a stalą 17-4PH oraz Inconelem 750 a stalą 17-4PH. W połączeniach spawanych plazmowo zaobserwowano częściowy brak przetopu. Spoina w połączeniu Inconel 625 - stal 17-4PH wykazuje strukturę austenityczną komórkowo-dendrytyczną (rys. 4). Pomiędzy materiałem rodzimym Inconel 625 a spoiną zachodzi krystalizacja epitaksjalna. W połączeniu Inconel 750 - stal 17-4PH przy linii wtopienia pomiędzy stalą 17-4PH a spoiną można zaobserwować płaski front krystalizacji (rys. 5). Spoina ma strukturę austenityczną komórkowo-dendrytyczną, przy czym ramiona dendrytów są mniej rozbudowane niż w przypadku złącza Inconel 625 - stal 17-4PH (rys. 6).

W mikrostrukturze strefy wpływu ciepła stopu Inconel 625 i Inconel 750 nie zaobserwowano istotnych zmian w porównaniu do materiału rodzimego. Na całej długości próbki widoczna jest struktura austenityczna. Wyraźne różnice występują w strukturze strefy wpływu ciepła w stali 17-4PH wraz z oddalaniem się od spoiny $\mathrm{w}$ kierunku materiału rodzimego (rys. 7). W czasie spawania stali 17-4PH w strefie wpływu zachodzą przemiany fazowe. Bezpośrednio przy linii wtopienia występuje gruboziarnisty ferryt $\delta$, który przy chłodzeniu przemienia się w austenit, a poniżej temperatury $M_{s}$ w martenzyt. W strukturze obok martenzytu mogą pozostać niewielkie ilości nieprzemienionego ferrytu $\delta$. W niższych temperaturach występuje obszar nagrzany podczas spawania do zakresu austenit + ferryt $\delta$. Ferryt $\delta$ występuje w postaci siatki na granicach ziaren i przy szybkim ponownym chłodzeniu nie ulegnie przemianie $\mathrm{w}$ austenit i potem w martenzyt. W strukturze będzie widoczny martenzyt z siatką ferrytu na granicach ziaren. W dalszej odległości od spoiny występuje obszar nagrzany podczas spawania do zakresu istnienia austenitu. Po ochłodzeniu w strukturze będzie

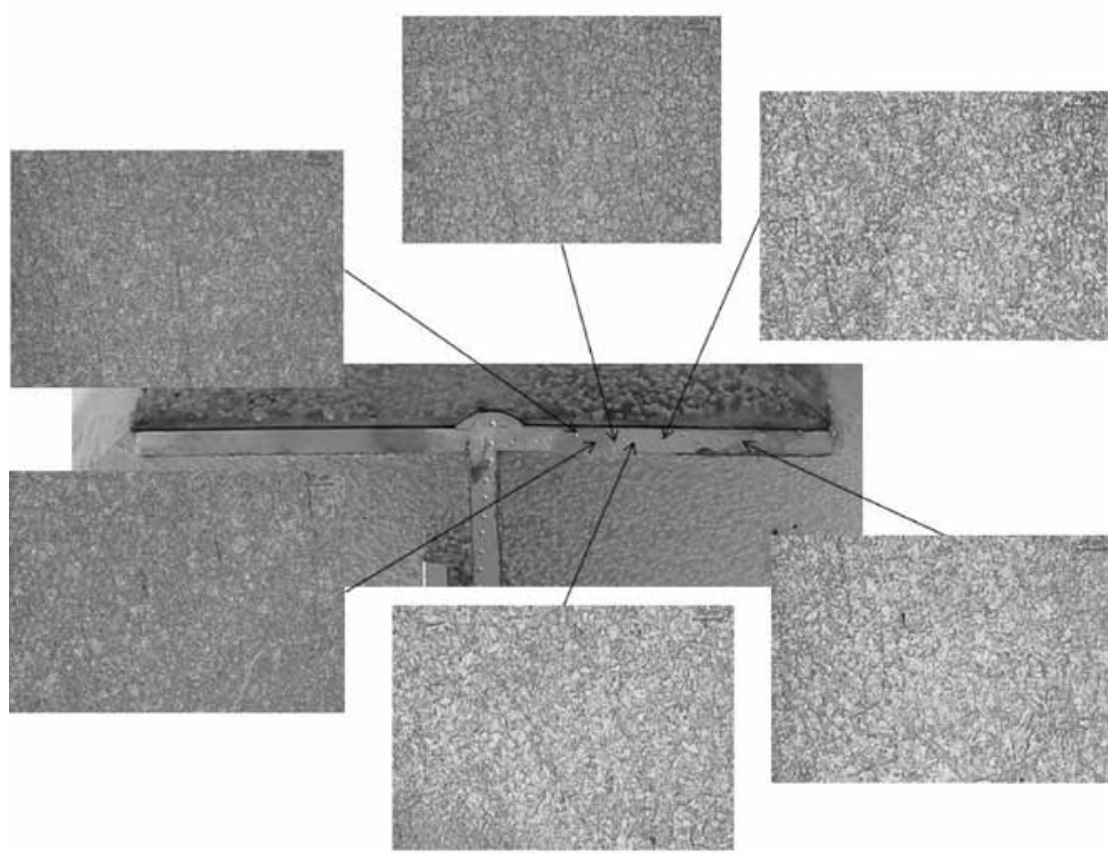

Rys. 7. Stal $17-4 \mathrm{PH}$, zmiany mikrostruktury w SWC złącza spawanego plazmowo Fig. 7. The 17-4PH steel, microstructure of the HAZ of the plasma weld 

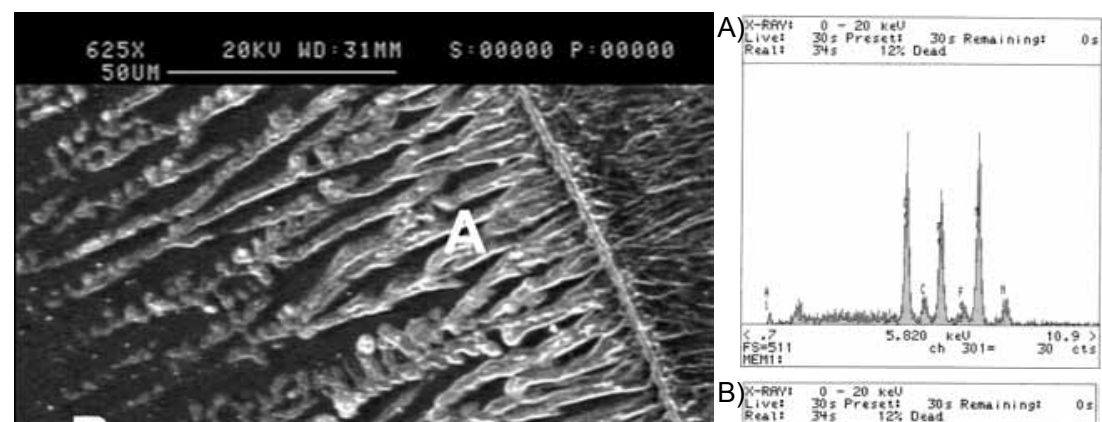

B
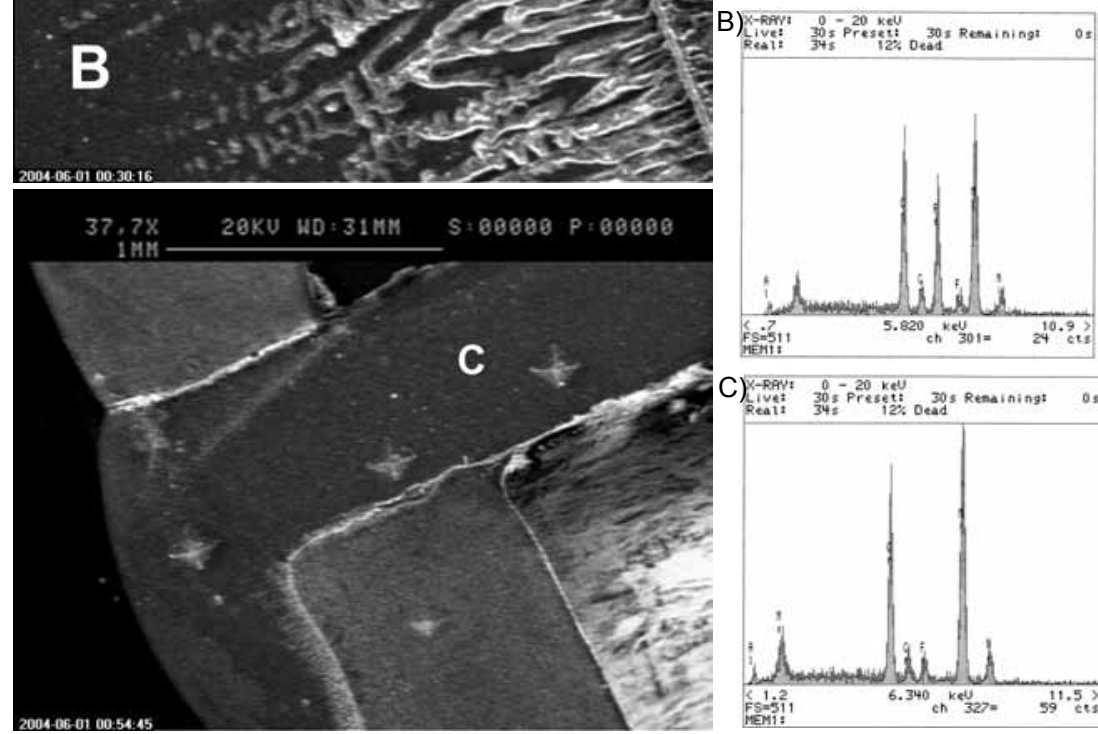

Rys. 8. Analiza jakościowa zawartości pierwiastków w złączu Inconel 625 - stal 17-4PH z zaznaczonymi miejscami analizy

Fig. 8. Quantitative analysis of the elements in Inconel 625 - 17-4PH welded joint; the analyzed areas are marked by capital letters A, B, C
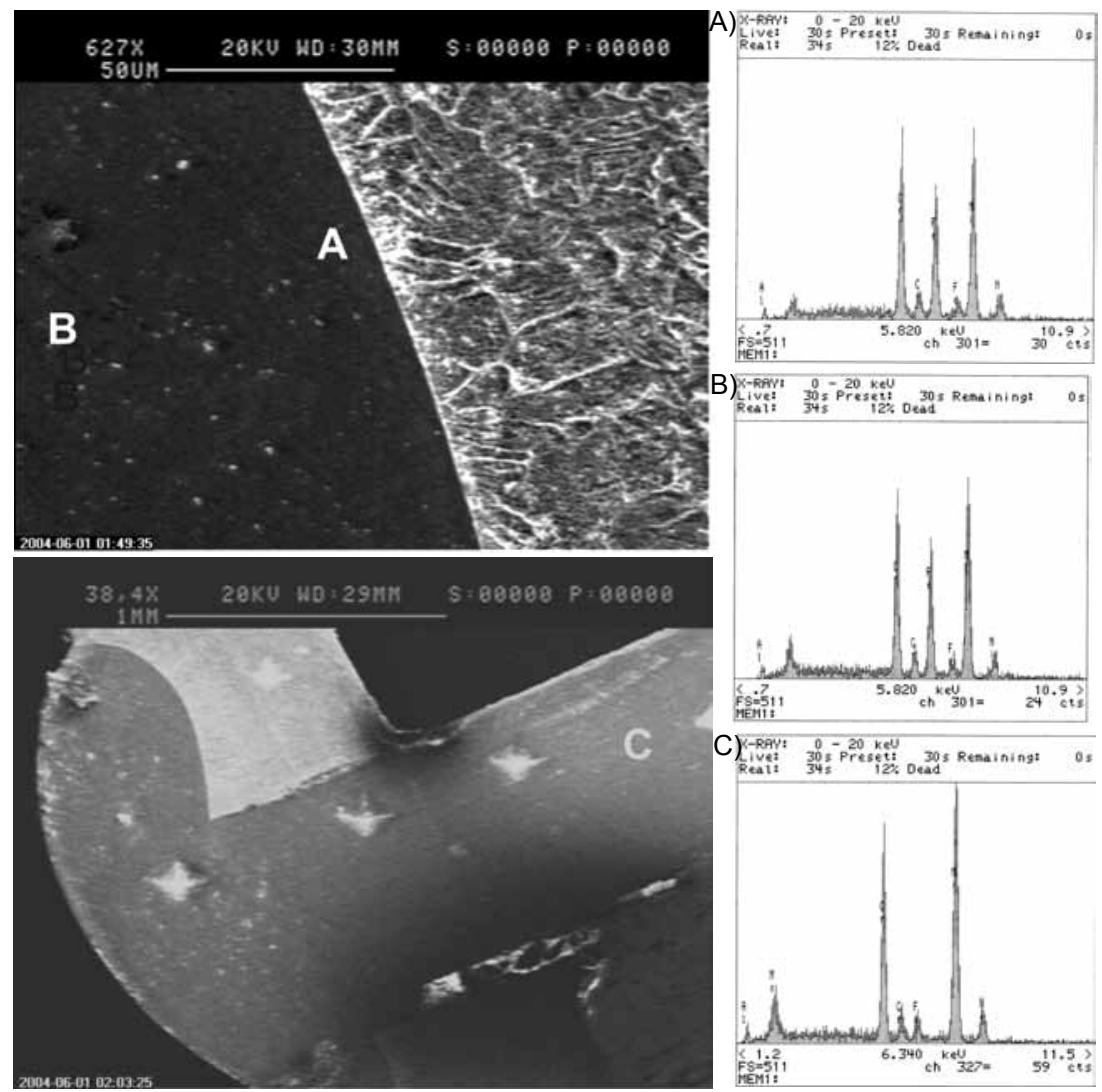

Rys. 9. Analiza jakościowa zawartości pierwiastków w złączu Inconel 750 - stal 17-4PH wraz z zaznaczonymi miejscami analizy

Fig. 9. Quantitative analysis of the elements in Inconel $750-17-4 \mathrm{PH}$ welded joint; the analyzed areas are marked by capital letters A, B, C. występował martenzyt. Obszar nagrzany do temperatury wyższej $\operatorname{od~} A_{c 1}$ będzie miał strukturę austenitu z martenzytem, a po ochłodzeniu - „świeżego” martenzytu na tle martenzytu odpuszczonego.

Badania jakościowe SEM z obszarów zaznaczonych na rysunku 7 wykazały, że w spoinie połączenia Inconel 625 - stal 17-4PH wraz z oddalaniem się od linii wtopienia w głąb spoiny pomiędzy stalą a spoiną wzrasta zawartość Mo oraz Ni. Intensywność pików pochodzących od Mo i Ni w spoinie jest mniejsza niż w przypadku intensywności tych pierwiastków w stopie Inconel 625 (rys. 8). Świadczy to o dobrym wymieszaniu stopu Inconel 625 ze stalą, chociaż stopień wymieszania nie jest jednakowy w całej spoinie. Spoina w połączeniu Inconel 750 stal 17-4PH również nie jest jednorodna. W spoinie przy linii wtopienia pomiędzy stalą a spoiną obserwuje się niską zawartość Ti i Ni w porównaniu do stopu Inconel 750 (rys. 9). W środku spoiny wyższe intensywności pików pochodzących od Ti, $\mathrm{Ni}$ oraz niższa intensywność piku pochodzącego od $\mathrm{Fe}$ świadczą o większym stopniu wymieszania ze stopem Inconel 750.

W celu sprawdzenia, czy niejednorodność występująca w spoinie ma wpływ ma właściwości połączenia, przeprowadzono badanie twardości. Wyniki pomiaru twardości wskazują, że spoiny w obu połączeniach charakteryzują się zauważalnie niższą twardością niż niklowy materiał rodzimy. Różnice w twardościach spoin przy linii wtopienia i w środku spoiny w przypadku obu połączeń były mniejsze niż $4 \%$. W połączeniu stal $17-4 \mathrm{PH}$ ze stopem Inconel 625 średnia twardość spoiny wynosi ok. $206 \mathrm{HV}$, natomiast w próbce połączenia stal 17-4PH ze stopem Inconel 750 ma wartość 151 HV. W przypadku Inconelu 750 w obszarze SWC zmierzono twardość 169 HV. Stanowi to niewielki spadek względem twardości materiału rodzimego, która oscyluje w granicach 180 HV (rys. 10). W stopie Inconel 625 mamy do czynienia z sytuacją odwrotną. W SWC twardość gwałtownie rośnie, do $274 \mathrm{HV}$, 


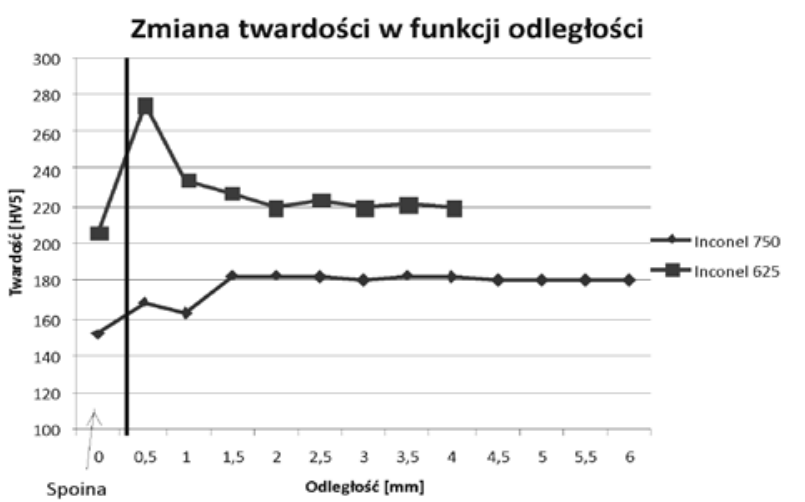

Rys. 10. Zależność twardości od odległości od spoiny w stopach Inconel 625 i Inconel 750

Fig. 10. Dependence of the hardness as a function of distance from the welded joint for Inconel 625 and Inconel 750

względem mierzonej w materiale rodzimym (ok. $220 \mathrm{HV}$ ). Może być to spowodowane nagrzaniem materiału podczas spawania do temperatury z zakresu starzenia, co mogło prowadzić do wzrostu twardości. Twardość w SWC w stali 17-4PH w pobliżu linii wtopienia jest mniejsza niż twardość materiału

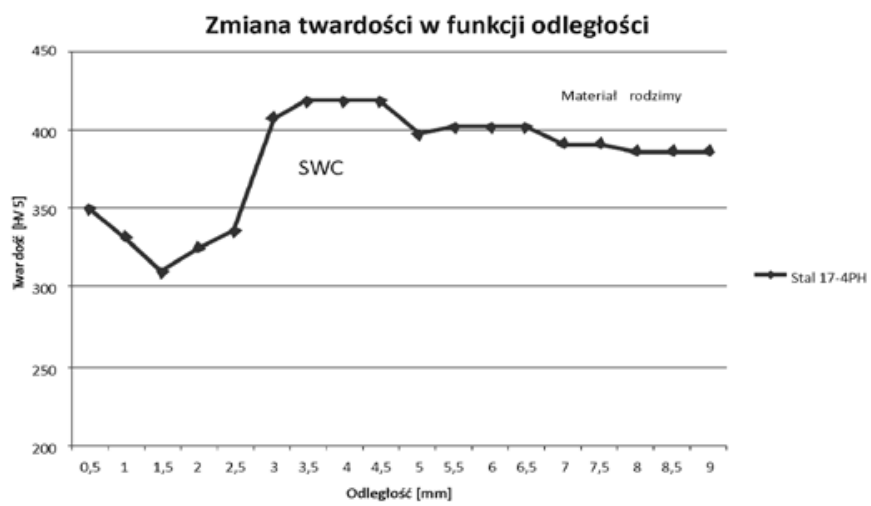

Rys. 11. Zależność twardości od odległości od spoiny w stali 17-4PH Fig. 11. Dependence of the hardness as a function of distance from the welded joint for 17-4PH stee

rodzimego. Może byćto spowodowane nagrzaniem tego obszaru podczas spawania do wysokiej temperatury i rozpuszczeniem fazy umacniającej. Najwyższą twardość zmierzono w odległości ok. 4,5 mm od linii wtopienia (rys. 11). W tym obszarze twardość wynosi $418 \mathrm{HV}$.

\section{Podsumowanie}

Przeprowadzone badania mikroskopowe połączeń różnorodnych pozwoliły ustalić, że spoiny mają strukturę austenityczną komórkowo-dendrytyczną, przy czym w połączeniu Inconel 750 - stal 17-4PH ramiona dendrytów są mniej rozbudowane niż w przypadku złącza Inconel 625 - stal $17-4 \mathrm{PH}$. W połączeniu Inconel 750 - stal 17-4PH przy linii wtopienia pomiędzy stalą $17-4 \mathrm{PH}$ a spoiną można zaobserwować płaski front krystalizacji. Badania jakościowe wykazały, że skład chemiczny spoiny zmienia się wraz z oddaleniem się od linii wtopienia. W spoinie połączenia Inconel 625 - stal $17-4 \mathrm{PH}$ wzrasta zawartość Mo oraz $\mathrm{Ni}$, natomiast w połączeniu Inconel 750 - stal 17-4PH zwiększa się zawartość Ti i Ni. Oznacza to, że spoina w tych połączeniach składa się w większym stopniu ze stopów niklu.

Różnice $w$ twardości spoin przy linii wtopienia i w środku spoiny w przypadku obu połączeń były minimalne. W połączeniu stal $17-4 \mathrm{PH}$ ze stopem
Inconel 625 średnia twardość spoiny wyniosła ok. $206 \mathrm{HV}$, natomiast w połączeniu stal 17-4 PH ze stopem Inconel 750 twardość spoiny przyjęła wartość $151 \mathrm{HV}$.

Zastosowana w badaniach procedura spawania plazmowego umożliwia otrzymanie połączeń różnorodnych stali nierdzewnej umacnianej wydzieleniowo ze stopami niklu Inconel 625 i Inconel 750 . Parametry procesu spawania plazmowego okazały się niewystarczające do otrzymania połączenia bez niezgodności spawalniczych. W obu przypadkach połączeń wystąpił brak przetopu, jednakże ta niezgodność spawalnicza nie dyskwalifikowała całego złącza spawanego. Badania wykazały, że metoda spawania plazmowego może być także stosowana przy otrzymywaniu połączeń różnorodnych stali $17-4 \mathrm{PH}$ ze stopami niklu. Przy zastosowaniu odpowiednich parametrów procesu można uzyskać złącze spawane o korzystnej mikrostrukturze.

\section{Literatura}

[1] Nowacki J.: Weldability of 17-4 PH stainless steel in centrifugal compressor impeller applications, Journal of Materials Processing Technology, vol. 157-158, Poland, 2004, s. 578-583.

[2] Choudhury I. A., El-Baradie M. A.: Machinability of nickel-base super alloys: a general review, Journal of Materials Processing Technology, vol. 77, Ireland, 1998, s. 278-284.

[3] Shiue R.K., Wu S.K., Shiue J.Y.: Infrared brazing of Ti-6Al$4 \mathrm{~V}$ and $17-4 \mathrm{PH}$ stainless steel with $(\mathrm{Ni}) / \mathrm{Cr}$ barrier layer(s), Material Science and Engineering A, vol. 488, Taiwan, 2008, s. $186-194$.
[4] Madej M.: Mikrostruktura i właściwości połączeń stali martenzytycznych umacnianych wydzieleniowo. Projekt inżynierski, AGH, Kraków, 2013.

[5] Guoge Z., Candel R.S., Seow H.P.: HNG Huey Hoon Microstructure of the interface of solid state difusion bond between Inconel alloy 718 and $17-4 \mathrm{PH}$ stainless steel.

[6] Ziewiec A., Tasak E., Czech J.: Welded joint cracking in martensitic stainless steel precipitation-strengthened with copper, Archives of Metallurgy and Materials, vol. 54, nr 4/2012.

Badania wykonano w ramach prac statutowych $\mathrm{nr}$ 11.11.110.156 